\title{
Pesticides in stormwater runoff-A mini review
}

\author{
Cheng Chen, Wenshan Guo, Huu Hao Ngo (ه) \\ Centre for Technology in Water and Wastewater, School of Civil and Environmental Engineering, University of Technology Sydney, \\ Sydney NSW 2007, Australia
}

\section{H I G H L I G H T S}

- The sources and pathways of pesticides into stormwater runoff were diverse.

- Factors affecting pesticides in stormwater runoff were critically reviewed.

- Pesticides mitigation strategies were included in this review.

- The current knowledge gap of the pesticides in stormwater runoff was identified.

\section{Keywords:}

Pesticide

Stormwater runoff

Occurrence

Urban runoff

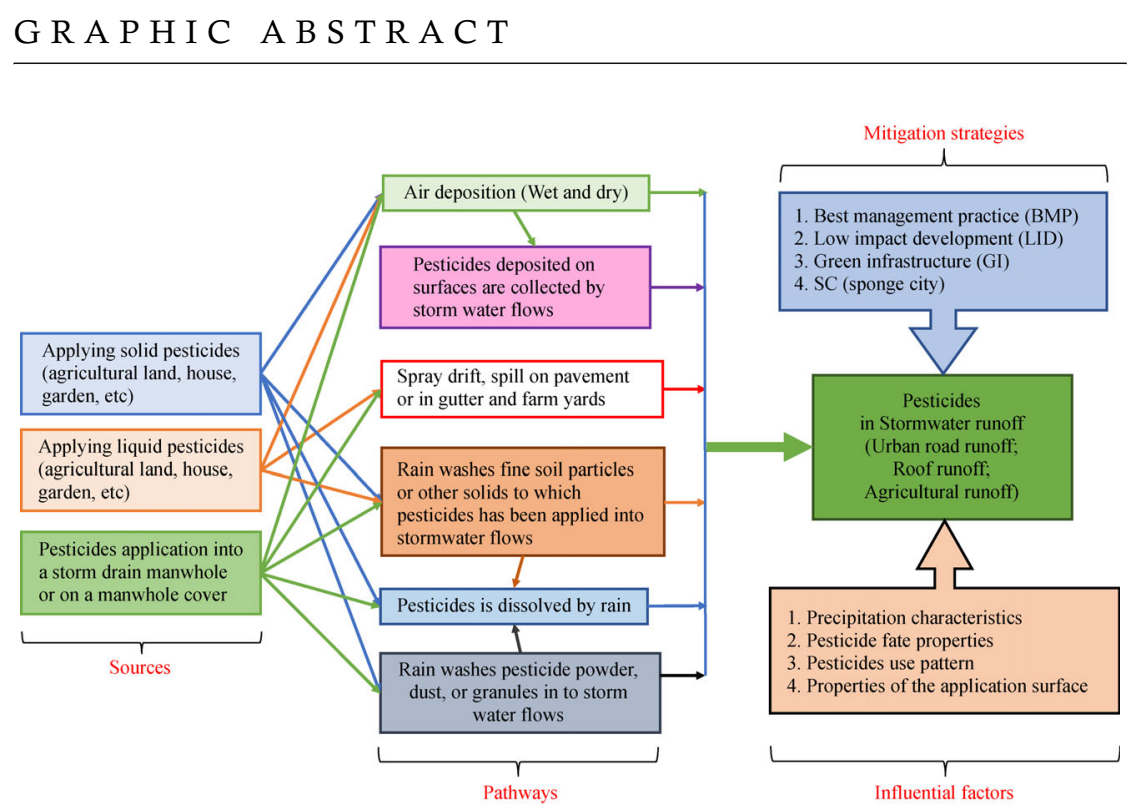

\section{A B S T R A C T}

Recently, scientific interest has grown in harvesting and treating stormwater for potable water use, in order to combat the serious global water scarcity issue. In this context, pesticides have been identified as the key knowledge gap as far as reusing stormwater is concerned. This paper reviewed the presence of pesticides in stormwater runoff in both rural and urban areas. Specifically, the sources of pesticide contamination and possible pathways were investigated in this review. Influential factors affecting pesticides in stormwater runoff were critically identified as: 1) characteristics of precipitation, 2) properties of pesticide, 3) patterns of pesticides use, and 4) properties of application surface. The available pesticide mitigation strategies including best management practice (BMP), low impact development (LID), green infrastructure (GI) and sponge city (SC) were also included in this paper. In the future, large-scale multi-catchment studies that directly evaluate pesticide concentrations in both urban and rural stormwater runoff will be of great importance for the development of effective pesticides treatment approaches and stormwater harvesting strategies.

\section{Introduction}

Pesticides have become not only crucial adjuncts of modern agriculture production systems resulting in increased crop yields, but also major components in residential and commercial maintenance tasks such as

$\triangle$ Corresponding author

E-mail: h.ngo@uts.edu.au indoor pest control and landscaping. In 2007, the application of pesticides for agricultural and urban purposes reached more than 2 million tonnes worldwide, at a cost of more than US\$39 billion (US EPA, 2011). Given the magnitude of global pesticide use, pesticide contamination of surface water, groundwater sediments, and soils is very widespread. Pesticides are known as the substances or mixtures intended for preventing, destroying, repelling or mitigating pests (Jurado et al., 2012). Throughout the world, $40 \%$ of applied pesticides are 
herbicides, $33 \%$ are insecticides, while $10 \%$ are fungicides and $17 \%$ are classified as bactericides (Glinski et al., 2018). Pesticides may enter water bodies through point and non-point sources (NPS), but NPS have emerged as the most important. Stormwater runoff and erosion, spraydrift, leaching, drainflows, and other sources including atmospheric transport and deposition of wind eroded soil are classic examples of typical pesticides NPS pollution (Reichenberger et al., 2007).

Stormwater runoff occurs when precipitation reaches the environment and rainfall flows over the ground surface. It is formed when rain falls on the surface of roofs, roads, highways, driveways, parking lots, agricultural areas, and other paved surfaces that do not allow water to soak into the ground. As one of the most common forms of NPS pollution, stormwater runoff has been recognized as a potential threat to human health and ecosystem wellbeing (Parker et al., 2010). This is attributed to the high concentrations of chemical and biological contaminants it carries that have been directly related to disease outbreaks, toxicity to aquatic life, and endangered quality of water sources. Pollutants deposit on the land and roof surfaces in dry periods, and as precipitation washes over these surfaces after heavy rain events, it picks up and transports a variety of pesticides, heavy metals, sediment, and animal fecal wastes in either dissolved or particulate form. Among them, pesticides belong to the most dangerous class because they are inherently designed to control the occurrence of pests, weeds, and other undesirable organisms in both urban and rural areas (Wittmer et al., 2010). Both precipitation and stormwater runoff eventually end up in surface waters and ground waters, which are the primary source of drinking water. Hence, surface and/or ground water are exposed to a wide variety of pesticides, which are harmful environmental pollutants because of their acute and chronic toxicity and long lifetime in the urban and agricultural environment (Wittmer et al., 2010). Moreover, there is a growing interest in using stormwater as an urban water resource to overcome water scarcity and security challenges, however, pesticides were identified as a key knowledge gap (Zhang et al., 2015).

Over the last few decades, the occurrence of pesticides in stormwater runoff has become a global issue of protecting the environment. Much of the pesticide pollution in stormwater runoff can be traced back to the pesticide use in crop and soil management practices in the agriculture sector. Furthermore, urban pesticide use presents its own environmental and human health risks so that urban pesticide exposure elevates the risk of lung cancer, non-Hodgkin lymphoma, and immune dysregulation (Rippy et al., 2017). Particularly, this situation is worsening since intensive urbanization has been altering the hydrological cycle due to increasing construction of impervious surfaces and subsequently, led to increasing stormwater runoff with deteriorated water quality. Knowledge of the source of pesticides in the resultant runoff, their occurrence and concentration in the environment, as well as the influential factors, is vital in managing the overall risk related to stormwater runoff.

Several review papers have been published on the occurrence of pesticides in groundwater (Jurado et al., 2012), and agricultural runoff since the early 1980s (Willis and McDowell, 1982). Rippy et al. (2017) focused on the occurrence and spatial-temporal variability in urban runoff in Australia while Luo et al. (2014) studied the occurrence of pesticides in the aquatic environment including wastewater treatment plants (WWTPs), surface water, ground water and drinking water. Despite growing recognition of pesticide impacts from stormwater runoff, an updated review that directly evaluates pesticide sources, occurrence, influencing factors in stormwater runoff remains rare. In this review, we systematically summarized the source and recent occurrence of various pesticides in stormwater runoff in both rural and urban areas. The factors affecting pesticides in stormwater runoff have also been critically reviewed. A brief overview of possible methods for alleviating pesticides pollution in stormwater runoff was also suggested in this review.

\section{Sources of pesticides from stormwater runoff}

Sources of pesticides from stormwater runoff are diverse and many of these originate from site applications for pest control purposes in both urban and agricultural areas. Figure 1 summarizes the sources and pathways of pesticides into stormwater runoff. It is of great necessity to investigate the different contamination pathways, so that the introduction of pesticides into stormwater runoff can be properly assessed and reduced. Once identified, viable reduction measures can then be used to prevent the pollution of stormwater by pesticides.

Unlike most rural or agricultural regions, residential areas are typically characterized by impervious surfaces (i. e. the artificial hard surface such as concrete), for up to $90 \%$ of the total surface area (Jiang et al., 2012). To control pests such as termites, cockroaches and poisonous insects, hard surfaces may be treated directly with insecticides directly for structural perimeter spray and trail eradication. Particularly, pyrethroid insecticides have been frequently detected in residential runoff since they have replaced organophosphates such as diazinon and chlorpyrifos for pest control in urban environments (Weston et al., 2009). Pesticide residues may also be transported onto the hard surface due to spray drift and wind or water-aided movement (Jiang et al., 2012). Herbicides are also employed for maintaining gardens and public greeneries in landscaping areas, hence rain and canopy throughfall from landscaping trees are also the input sources for pesticides in stormwater runoff (Zhang et al., 2011). There are also cases where direct pesticide application into a 


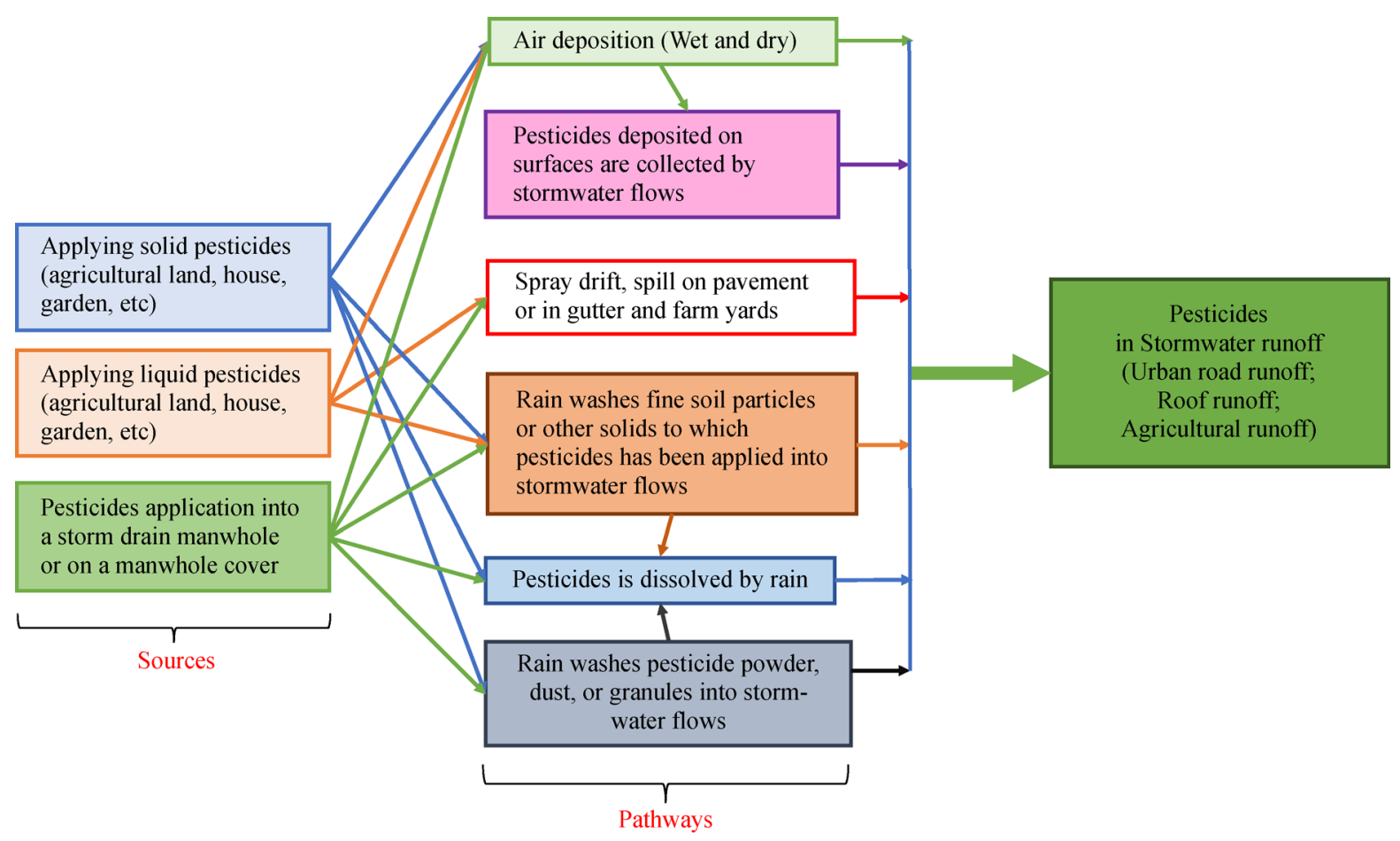

Fig. 1 The sources and pathways of pesticides into stormwater runoff.

storm drain manhole or on a manhole cover is applied. When the precipitation occurs, pesticides are either dissolved by rain, or rain washes pesticides granules or fine particles to which pesticides have been applied into the stormwater flow (Parker et al., 2010). Pesticides can also enter the atmosphere predominantly by means of evaporation during their application or evaporation from buildings, soil or plant surfaces after application (Vialle et al., 2013). Pesticides deposited from the atmosphere onto the surfaces do not only originate from local sources, but also from long-range atmospheric transport (Zabik and Seiber, 1993). The wet or dry pesticide depositions on surfaces are also collected by stormwater flows during rainfall events.

In rural areas, agricultural runoff is the main process whereby pesticides are transported in solved or particulate forms along the surface of sloping agricultural land. Due to the extensive use of pesticides for enhancing crop production, the transport of pesticides to the stormwater runoff during rain events in the application season is significant. Mangiafico et al. (2005) analyzed the pesticides in stormwater runoff in production nurseries and citrus and avocado groves in California. They suggested that the pesticide runoff from precipitation events after dormant season application is the major concern since rainfall primarily occurs in the winter months when crop growth and biological activity may be limited. On the other hand, pesticide applications are typically implemented as sprays which are formed when the liquid is atomized through a hydraulic nozzle (Stephenson et al., 2006). So, pesticides' drift is another important process by which losses of pesticides to stormwater runoff occurs during or after rainfall events. This process is defined as one where the fine fraction (i.e. pesticides droplets or vapor) is moved by wind beyond the intended area of application, causing off-target pesticides movement (Vymazal and Březinová, 2015).

\section{Occurrence of pesticides in stormwater runoff}

\subsection{Urban stormwater runoff}

Urban runoff consists of a collection of pesticides from several input sources, including rain and canopy throughfall from landscaping trees, garden runoff, roof runoff, road runoff and so on. Urbanization has led to an increase in urban runoff, accompanied with a decline in water quality during rain events. Pesticide runoff in urban area differs significantly from an agricultural land in which runoff and infiltration typically occur over a relatively homogeneous soil surface (Huang et al., 2004b). Urban runoff occurs from the road surface, the application zone, and the adjacent vegetated slope, and hence, most of the rain falling on the impervious surface becomes surface runoff. Particularly, when berms are absent, this runoff can pass directly over the application zone, intensifying the pesticide leaching potential of a particular storm. The reported pesticide concentrations varied significantly, 
ranging from below the detection limit to $>100 \mathrm{mg} / \mathrm{L}$ (Gasperi et al., 2014). Burant et al. (2018) investigated pesticides in urban runoff in association with urban land use in the US. The study therefore, compared the occurrence and concentration trends of pesticides in a high-density residential site and commercial strip site. They found that the sum of the total measured pesticides revealed no significant difference between sites, which was likely due to the considerable green space and associated pesticide use at both sites, highlighting the importance of agricultural pesticides use in urban areas due to atmospheric transport and deposition. Rippy et al. (2017) examined pesticide occurrence in urban stormwater throughout Australia. Overall, stormwater pesticide concentrations were found to be relatively smaller than reported in other countries (including the United States, Canada and Europe). Of the 27 pesticides evaluated, 19 were detected in stormwater in Australia, with five pesticides (i.e. diuron, MCPA, 2,4-D, simazine, and triclopyr) found in more than half of samples. Vialle et al. (2013) evaluated the pesticides concentration in roof runoff waters from an urban agglomeration in France. More than 400 pesticides and metabolites on the priority list of the European Union were screened over a year. Fifteen compounds were quantified, and only 4 were detected more than once over the 12 samples. The majority of compounds observed were herbicides, with fungicides and metabolites as the second and third most common compounds detected. The results confirmed that the presence of pesticides in roof runoff in suburban sites was impacted more by local agricultural activities rather than urban practices.

Organochlorine pesticides (OCPs) are the most important species of pesticides due to their chronic toxicity, persistence, and bioaccumulation. Early work conducted by the US Geological Survey (Oltmann and Shulters, 1989) revealed the elevated concentrations of organophosphorous and organochlorine pesticides in rain and road runoff in Fresno, California. Zhang et al. (2011) discovered that the contribution of OCPs from rain and canopy throughfall to urban runoff was significant in big cities such as Beijing in China, due to a historically large-scale ongoing use and observed fresh signatures. The average unit loading rates of OCPs in urban runoff were found as follows: hexachlorobenzene (HCB) at $17.7 \mathrm{~g} / \mathrm{km}^{2} / \mathrm{a}$; hexachlorocy-clohexanes (HCHs) at $58.8 \mathrm{~g} / \mathrm{km}^{2} / \mathrm{a}$; and dichlorodiphenyltrichloroethanes (DDTs) at $21.9 \mathrm{~g} / \mathrm{km}^{2} / \mathrm{a}$. OCPs in urban runoff were transported from various sources such as rain, dust, and canopy throughfall. In runoff, DDTs and HCB were primarily from dust, while $\mathrm{HCHs}$ were mainly transported from rain and canopy throughfall (Zhang et al., 2010). In the cities of developing countries currently undergoing rapid urban sprawl, OCPs concentrations should be monitored and controlled effectively since runoff from highly urbanized watersheds can carry a substantial amount of OCPs and be potentially detrimental to urban water systems (Zhang et al., 2011). In the US, pyrethroid insecticides have been regularly used to replace organophosphates for pest control in urban areas and often detected in residential runoff at toxicologically significant concentrations (Weston et al., 2009). Bifenthrin was detected most frequently with median maximum concentrations at 5-17 ng/L and $73 \mathrm{ng} / \mathrm{L}$, respectively. Other pyrethroids frequently detected were cyfluthrin (up to $23 \mathrm{ng} / \mathrm{L}$ ) and permethrin (up to $125 \mathrm{ng} / \mathrm{L}$ ). In another study, Chinen et al. (2016) reported the concentration of detected pyrethroids at $5.1-1408 \mathrm{ng} / \mathrm{g}$ dry weight in October 2013 and 11-1210 ng/g dry weight in February 2014; this difference was attributed to the size of the storm event during the sampling time.

There are also other studies that have concentrated on quantifying the specific pesticides, particularly for atrazine, simazine, and diuron in urban road runoff in Europe (Stachel et al., 2010). In Poland, Polkowska et al. (2001) determined the concentrations of 19 types of nitro-, chloro-, and phosphoro-organic pesticides in that country's urban road runoff and suggested that the highest concentrations were observed for atrazine, propazine and simazine. Herbicides runoff along highways has been deemed a significant pathway to urban runoff in the US due to the wide use of herbicides for controlling the roadside vegetation (Huang et al., 2004a). Huang et al. (2004b) monitored the concentrations of herbicides in runoff for up to 11 storms following herbicide application. Five herbicides were studied, namely isoxaben, oryzalin, diuron, clopyralid, and glyphosate, and each herbicide in each storm was monitored. The concentration of oryzalin was reported as $0-43.13 \mu \mathrm{g} / \mathrm{L}$. The least soluble compounds such as isoxaben and oryzalin were detected in all storms monitored while the more soluble compounds including diuron and clopyralid were found below detection limits. Previous research also focused on the determination of pesticides in roof runoff (Bollmann et al., 2014; Rippy et al., 2017). Bucheli et al. (1998a) investigated the occurrence and behavior of triazines, acetamides and phenoxy acids pesticides in roof runoff in Switzerland, and they found highest pesticide concentrations originating predominantly from agricultural use occurred during and immediately after application. Vialle et al. (2013) found the most frequently detected pesticides in suburban roof runoff were mecoprop (100\%) and DNOC $(75 \%)$. The largest measured concentrations were for mecoprop $(4.8 \mathrm{mg} / \mathrm{L})$ while up to hundreds of $\mathrm{ng} / \mathrm{L}$ were measured for DNOC, metaldehyde, 2,4-MCPA, and metolachlor. The occurrence of mecoprop in roof runoff at the suburban site was found at $100 \%$. Mecoprop is a frequently used roof-protecting agent, which means that such compound originates from the roofing material itself. The release of mecoprop is significant when high ambient temperature appears. Thus, the maximum concentration was found in the summer. This observation was in agreement with findings reported by Bucheli et al. 
(1998b). Polkowska et al. (2009) focused on determining the level of organonitrogen, organochlorine and organophosphorus pesticides in roof runoff waters. Bromofos, heptachlor epoxide and o.p'-DDE were the most often detected pesticides species in the roof runoff samples. Their study also suggested that pesticide levels in runoff were higher than in precipitation for samples collected from roofs. Pesticides could originate either from the roofing material itself, or from the dry deposition and/or adsorption of vapors during dry spells.

\subsection{Rural stormwater runoff}

Rural areas are mainly characterized by agricultural land and very low-density residential areas. Pesticide concentrations in runoff from agricultural regions were found to be more variable than those in urban runoff during the storm hydrograph (Kratzer, 1988). Types of pesticides detected were consistent with the agricultural practices in the region (Vialle et al., 2013). In rural areas, herbicides are predominantly used, with fungicides being the next most common. However, insecticides are used only to a minor extent. In Europe, Vialle et al. (2013) conducted a comparable study on the pesticide pollution in roof runoff between a rural site and a suburban one. Of the 405 pesticides and metabolites analyzed, 34 were detected more than once in samples collected at the roof in the rural site, where 26 were found above the quantification limit at least once. Particularly, for the rural site, the highest concentrations were recorded for glyphosate $(6 \mathrm{mg} / \mathrm{L})$. In addition, the most frequently detected pesticides were glyphosate, DNOC, AMPA, metolachlor $(\mathrm{R}+\mathrm{S})$, carbendazim, and 2,4-MCPA at $83 \%, 75 \%, 58 \%, 58 \%, 50 \%$, and $50 \%$, respectively. Moreover, concentrations up to several hundreds of ng/L were quantified for AMPA, metolachlor, DNOC and metaldehyde in decreasing concentrations order. The observation of the Pearson's correlation table revealed strong correlations against the occurrence of two groups of compounds. For the first group, the concomitant presence of certain compounds (e.g. glyphosate, dimethomorph, iprovalicarb, tebuconazole and boscalid) in the rural area was the result of the proximity with a vineyard. Compounds comprising the second group (e.g. acetochlor, pendimethaline, metolachlor, aclonifen and carbendazim) were more characteristic of pesticides used on crops management. Ninety-nine different pesticides including most of the semi-polar and polar ones commonly used in Swedish agriculture were studied in Sandin et al. (2018)'s comprehensive research on the spatial and temporal patterns of pesticide concentrations in runoff in a small Swedish agricultural catchment. In Japan, Nakano et al. (2004) surveyed the runoff characteristics of 9 different herbicides: bromobutide, simetryn, esprocarb, dimethametryn, pretilachlor, dymron, pyributicarb, piperophos and mefenacet. The maximum concentration of each soluble pesticide was found to be much higher than those in adsorbed form with concentrations at $<0.6 \mathrm{ppb}$

Glinski et al. (2018) targeted 160 pesticides and analyzed pesticide concentrations in agricultural areas by looking at three aspects surface water, stemflow (water flowing down the trunk of a tree during a rain event) and throughfall (water from tree canopy only) in South Georgia, US. The most frequently detected herbicide, fungicide, and insecticide were found as follows: metolachlor, tebuconazole, and fipronil, respectively, irrespective of sample origin. The most commonly detected pesticide in surface water and stemflow samples was metolachlor at $0.09-10.5 \mathrm{mg} / \mathrm{L}$, while the most frequently detected pesticide in throughfall samples was biphenyl at 0.02$0.07 \mathrm{mg} / \mathrm{L}$. Domagalski (1996) investigated the pesticides in stormwater runoff within the Sacramento River Basin, California. Diazinon and methidathion (organophosphate insecticides), molinate and carbofuran (carbamate pesticides), and one simazine (triazine herbicide) were detected in the runoff samples. Given the rising importance of hydrographs, concentrations of organophosphate pesticide were observed to be increasing, and peak concentrations were detected near peak discharge. Simazine, the herbicide applied for the purpose of controlling weeds along the roadways, was detected in the storm runoff, and it ranged from near the detection limit to $1.35 \mathrm{mg} / \mathrm{L}$. Kratzer (1988) compared the occurrence, concentrations, and loads of dissolved pesticides in storm runoff between two contrasting land uses (i.e. urban area vs. agricultural area) in the Tuolumne River Basin, California. Six types of pesticides were detected in agricultural stormwater runoff while 15 types of pesticides were found in urban stormwater runoff. Diazinon, chlorpyrifos, metolachlor, DCPA, and simazine were observed in almost every sample. Except for napropamide and simazine, median levels of pesticides were higher in the runoff from urban region. The greater occurrence and concentrations in storm drains were observed, which was partly resulted from the dilution of agricultural runoff samples by non-storm baseflow in the Tuolumne River and by storm runoff from non-agricultural land. Nevertheless, none of the samples had pesticide concentrations that exceeded drinking water criteria.

Topaz et al. (2018) characterized pesticide load dynamics during stormwater flow events on agricultural land in Israel, and their analysis was done by conducting high-resolution sampling campaigns of seven flood events during two rainy seasons in Alexander stream, Israel. Out of 250 pesticides investigated, a mixture of 63 pesticides was detected, with diuron (herbicide) and tebuconazole (fungicide) dominating. It was suggested that the coupling between flood event magnitude and pesticide application timing and methodology directly influenced potential aquatic toxicity of pesticides. However, in this study, the effects of geochemical conditions, which are dynamic due to sediment deposition or resuspension, water salinity, or dissolved oxygen concentrations, are not considered, hence limiting the application of this work and requiring 
further research. Hudak and Banks (2006) examined the occurrence of pesticides, including diazinon, triazine and chlorpyrifos, respectively, in the stormwater runoff in rural watersheds in north-central Texas in the United States. Pesticides were present in most samples; however, few samples were reported above drinking water maximum contaminant levels (MCLs). Five percent of composite diazinon and triazine observations exceeded MCLs. Diazinon is widely used for the insect management and control in lawns and landscaping around houses and other buildings while atrazine is a commonly applied triazine herbicide in both residential and agricultural applications in the study areas. As a result of a mild winter climate in the study area, pesticides are applied all year-round, but they are more frequent in the spring and summer. Particularly, larger amounts were detected in an initial spring storm event following applications to control weeds and insects.

\section{Factors affecting pesticides in stormwater runoff}

The concentration and spatial distribution of pesticides can be greatly affected by many factors, including characteristics of precipitation, pesticide fate properties, pesticides use pattern, and properties of the application surface. There is an urgent necessity to keep monitoring and control of the above-mentioned factors so that the transport of pesticides in stormwater runoff and environmental hazards in aquatic environments can be effectively managed. Table 1 provides a critical summary of some influential factors on the occurrence of pesticides in stormwater runoff.

\subsection{Characteristics of precipitation}

Rainfall characteristics including intensity and durations are of great importance in determining the pesticide loss in runoff (Willis and McDowell, 1982). Generally, the greatest amount of pesticide lost in runoff occurs when rainfall intensity is high and rainfall amount is large. The rainfall intensity significantly affects pesticide concentrations in stormwater runoff, particularly from soil surface, due to higher extraction efficiency and/or enhanced soil erosion at higher rainfall intensities (Müller et al., 2004; Revitt et al., 2002). Huang et al. (2004b) suggested that, for a given pesticide and site, the most crucial elements that determined seasonal herbicide loss in stormwater runoff were the timing and intensity of the first storm following application, and they can significantly affect total seasonal runoff by up to 2 orders of magnitude. Johnson (1995) observed a 10-fold increase in isoproturon loss in runoff in response to a 4-fold increase in rainfall intensity. Nevertheless, studies have identified precipitation intensity as having little effect on the concentrations of pyrethroid in runoff on hardened concrete surface in urban scenarios (Jiang et al., 2012; Jorgenson and Young, 2010). Hardened concrete is designed to form a solid material and cured to resist water erosion while soils consist of erodible aggregates. Therefore, higher precipitation intensity will not necessarily facilitate the removal of pesticides from concrete. Kratzer (1988) found all peak pesticide concentrations in agricultural stormwater runoff in the Tuolumne River at Modesto occurred during the rising limb of the storm hydrograph, whereas peak concentrations in the samples of urban runoff in the McHenry Storm Drain occurred at varying times during the storm hydrograph. Diazinon and chlorpyrifos concentrations in urban stormwater runoff increased gradually throughout the storm hydrograph, with peak concentrations occurring in the last sample. Chinen et al. (2016) suggested that the seasonal nature of the rainfall in Los Angeles, California creates a long dry period, and this may allow pyrethroids to be degraded. Therefore, an evaluation of the typical half-life of the various pyrethroids can reveal opportunities to reduce emissions to the receiving water by managing application times.

\subsection{Pesticide properties}

Pesticide properties, including formulation, mobility and solubility, and the chemical and physical properties that determine compound persistence, are critical factors in determining the concentrations of stormwater runoff (Willis and McDowell, 1982). Among these properties, the octanol-water partition coefficient $\left(\mathrm{K}_{\mathrm{ow}}\right)$ and the water solubility $\left(\mathrm{S}_{\mathrm{w}}\right)$ are the most valuable parameters (Jurado et al., 2012). The octanol-water partition coefficient is usually expressed as $\log \mathrm{K}_{\mathrm{ow}}$. It measures the level of hydrophilicity $\left(\log \mathrm{K}_{\mathrm{ow}}<4\right)$ or hydrophobicity $\left(\log \mathrm{K}_{\mathrm{ow}}>4\right)$ of a specific pesticide. Hydrophobic pesticides have a tendency to bioaccumulate and usually have a high capacity of adsorption, particularly onto organic matter. Conversely, pesticides with low $\log \mathrm{K}_{\mathrm{ow}}$ values tend to possess high $\mathrm{S}_{\mathrm{w}}$ and both lower bioaccumulation potential and soil/sediment adsorption coefficients (Jurado et al., 2012). However, cation must be taken carefully since log $\mathrm{K}_{\mathrm{ow}}$ does not always correlate with adsorption capacity onto mineral sediments. Willis and McDowell (1982) reported that pesticides that were water-insoluble generally produce greater long-term losses than those that are soluble while pesticides formulated in wettable powders produce the highest long-term losses. The runoff rate tends to rise with increased water solubility of pesticides. Nakano et al. (2004), however, found that the herbicide runoff rates were closely related to $\log \mathrm{K}_{\mathrm{ow}}$, rather than $\mathrm{S}_{\mathrm{w}}$ of herbicides. In their study, the concentration of dymron was found to be high in runoff, despite the fact its water solubility was much poorer. This might be attributed to the fact that chemicals adsorbed weakly onto the soil surface were 
Table 1 A summary of influential factors on the pesticides in stormwater runoff

\begin{tabular}{|c|c|}
\hline Factors & The effects on pesticides in stormwater runoff \\
\hline \multirow[t]{4}{*}{ Precipitation characteristics } & $\begin{array}{l}\text { For a given pesticide and site, the most vital factors in determining seasonal herbicide lost in } \\
\text { stormwater runoff were the timing and intensity of the first storm following application, } \\
\text { affecting total seasonal runoff by up to } 2 \text { orders of magnitude. }\end{array}$ \\
\hline & $\begin{array}{l}\text { The rainfall intensity played an important role in determining pesticide concentrations in } \\
\text { stormwater runoff from soil surface. }\end{array}$ \\
\hline & $\begin{array}{l}\text { A } 10 \text {-fold increase in the application loss of isoproturon was observed in response to a } 4 \text {-fold } \\
\text { increase in rainfall intensity. }\end{array}$ \\
\hline & $\begin{array}{l}\text { Precipitation intensity had little effect on the pyrethroid concentrations in runoff on hardened } \\
\text { concrete surface. }\end{array}$ \\
\hline
\end{tabular}

Pesticide fate properties

Pesticides use pattern

Properties of the application surface
The herbicide runoff rates were correlated fairly well with octanol-water partition coefficient $\left(\log \mathrm{K}_{\mathrm{ow}}\right)$, rather than with water solubility of herbicides

Pesticide concentration was determined by formulation and solubility, and the physiochemical Willis and McDowell (1982) properties that decides a compound's persistence.

For rain and roof runoff, maximum pesticide concentrations originating primarily from agricultural use occurred during and right after the application periods.

For a given pesticide and site, the most vital factors in determining seasonal herbicide lost in stormwater runoff were the timing and intensity of the first storm following application, affecting total seasonal runoff by up to 2 orders of magnitude.

Highest number and concentrations of pesticides were detected at the end of spring and through summer, which are consistent with treatment periods and higher temperatures.

For concrete slabs subjected to natural rainfalls during the winter wet season, pesticide levels in the runoff decreased as the time interval between pesticide application and the rain event increased.

Pesticide concentrations were higher in an initial spring storm event following applications to control weeds and insects.

Spray drift can result in subsequent rain events washing pesticides off trees in buffer zones leading to higher concentrations in nearby stormwater runoff.

Spray drift associated with volatilization may cause pesticides deposition in the atmosphere, resulting in substantial amounts in rainwater far from application sites.

Compared to insecticides and herbicides, fungicides were more frequently detected in US, because of their more frequent, intensive application schedules in spite of lower application rates.

Pesticide concentrations tend to follow seasonal trends with lower concentrations in winter and after crop harvesting and higher concentrations detected during periods of heavy use.

More variations in pesticide concentrations throughout the storm hydrograph were observed for samples of agricultural runoff than samples of urban runoff.

Higher pesticide concentrations were observed in runoff waters collected from roofs covered with galvanized sheet metal and ceramic tiles.

Depending on the nature of roofing material used for rainwater collection, stormwater runoff can be contaminated with mecoprop, which is a roof protecting agent.

The dry nature of the urban catchment at the time of the storm can result in low runoff volumes and peak flow values.

A catchment with a high proportion of impervious surface area generates greater urban runoff.

Runoff from highly urbanized watersheds can carry a substantial amount of OCPs and be potentially dangerous to urban water systems.

The runoff transferability of pyrethroid residues from concrete is not significantly affected by concrete surface conditions

Densely populated areas in urban watersheds with a high factor of impervious surfaces produce the highest amount of synthetic pyrethroids (SPs) runoff.
Müller et al. (2004);

Revitt et al. (2002)

Johnson (1995)

Jiang et al. (2012;

Jorgenson and Young (2010)

Nakano et al. (2004)

Bucheli et al. (1998a)

Huang et al. (2004b)

Vialle et al. (2013)

Jiang et al. (2012)

Hudak and Banks (2006)

Glinski et al. (2018)

Battaglin et al. (2016)

Konstantinou et al. (2006)

Kratzer (1988)

Polkowska et al. (2009)

Vialle et al. (2013)

Revitt et al. (2002)

Zhang et al. (2011)

Jiang et al. (2012)

Chinen et al. (2016)

Revitt et al. (2002)

Catchment with a significant soil moisture deficit generates low runoff volumes. 
gradually desorbed in the course of a certain period after the pesticide applications. Subsequently, in this case, the runoff rates of the pesticides were strongly affected by their hydrophobic properties as well as water solubilities (Nakano et al., 2004). Pesticide persistence is usually measured in terms of half-life $\left(\mathrm{T}_{\mathrm{n}}\right)$, the time required for $50 \%$ of the pesticide to disappear. With the greater persistence, the longer the pesticide is available to runoff forces, and the greater the potential loss by runoff (Willis and McDowell, 1982).

\subsection{Pesticides use pattern}

The time interval between pesticide application and rainfall exerts an influential impact on pesticides in stormwater runoff. Most major losses of pesticides in stormwater runoff occur when a substantial amount of rainfall occurs during and immediately following the application periods. For stormwater runoff in a rural area, maximum pesticide concentrations originated mainly from agricultural use occurs during and right after application (Bucheli et al., 1998a). For urban stormwater runoff derived from concrete slabs during the winter wet season, pesticide levels in the runoff decreased as the time interval between pesticide application and the rain event increased (Jiang et al., 2012). Depending on the pesticide application schedule, pesticide concentrations follow seasonal trends with smaller concentrations in winter and after crop harvesting while higher concentrations were detected during periods of heavy use (Konstantinou et al., 2006). Hudak and Banks (2006) found higher pesticide concentrations in an initial spring storm event following applications for controlling weeds and insects. Vialle et al. (2013) observed the highest number and concentrations of pesticides at the end of spring and through summer, and found they were consistent with treatment periods and higher temperatures. Compared to insecticides and herbicides, fungicides were more frequently detected pesticides in the US, due to their more frequent and intensive application schedules in spite of lower application rates (Battaglin et al., 2016). Given the inherent problems that characterize the application method, spray drift which is something that is difficult to avoid, can cause subsequent rain events washing pesticides off trees in buffer zones. The result of this is increased concentrations in nearby stormwater runoff (Glinski et al., 2018). Moreover, volatilization associated with spray drift may cause pesticides being deposited in the atmosphere, resulting in substantial amounts in rainwater ending up a long way from the application sites. Kratzer (1988) discovered the high concentrations of diazinon in rainfall in urban areas of San Joaquin Valley during the dormantorchard spray period. However, the answer to whether the diazinon in the storm drains originates from drift or volatilization from applications on neighboring agricultural areas or from urban applications is still unknown and this requires further study.

\subsection{Properties of the application surface}

In terms of soil texture and topography in the application surface, higher pesticide losses in stormwater runoff generally occur from fine-textured soils rather than coarse textured soils or soils with greater slopes (Willis and McDowell, 1982). This is because coarse-textured soils present higher infiltration rates and lower erosion and runoff volume while steep slope brings higher runoff volume and erosion. With regard to antecedent moisture, moist and wet soils can produce higher amounts of pesticides in the stormwater runoff than those with dry soils, which means that a significant soil moisture deficit promotes low runoff volumes (Revitt et al., 2002). For pesticide runoff in agricultural area, ground cover such as crop residues can help reduce the loss of water-insoluble pesticides to stormwater runoff due to a reduction in erosion (Willis and McDowell, 1982). Nevertheless, an increase in crop residues may increase concentrations of water-soluble pesticides in stormwater runoff. The imperviousness of the application surface is an important aspect that affects pesticides in stormwater runoff. Cities with a generally all-encompassing or wide impervious surface area generate greater runoff, while the dry nature of the impervious urban catchment at the time of the storm can result in low runoff volumes and peak flow values. As a result of the undergoing rapid urban expansion, stormwater runoff in highly urbanized watersheds tend to possess a substantial concentration of OCPs and poses a potential threat to the local urban water systems (Zhang et al., 2011). Similarly, Chinen et al. (2016) reported that highly impervious urban areas can produce the largest amounts of synthetic pyrethroids (SPs) runoff. Hence, the focus should be made on the residential and commercial land uses which were identified as the highest level of dischargers. Moreover, minimizing pyrethroid usage, especially those with the longest half-lives in urban area is in great need. In one study, Kratzer (1988) found pesticide concentrations varied much more greatly throughout the storm hydrograph for samples of agricultural runoff than those of urban runoff. Depending on the choices of roof material, stormwater runoff can be contaminated with mecoprop, a common roof protecting agent (Vialle et al., 2013). Higher pesticide levels were observed in runoff waters collected from roofs covered with galvanized sheet metal and ceramic tiles (Polkowska et al., 2009).

\section{Mitigation strategies to reduce pesticides in stormwater runoff}

The most effective and straightforward way to minimize pesticide levels in stormwater runoff is to reduce the associated sources of pesticides application (Wang et al., 2019). Nevertheless, the reduction in pesticide usage may 
not be accepted as an economically feasible approach as it might cause crop yield reduction, thus resulting in the loss of farm household incomes. Alternatively, other mitigation strategies including best management practice (BMP), low impact development (LID), green infrastructure (GI) and sponge city (SC) should be considered to alleviate the transport of pesticides from applied fields to receiving stormwater runoff.

Commonly applied structural BMPs for the management of pesticides in stormwater runoff include, but are not limited to, strip cropping, vegetated filter strips (VFS), grassed waterways, constructed wetlands and sediment ponds, and pesticide use reduction (Zhang and Zhang, 2011; Wang et al., 2019). These BMPs have demonstrated their effectiveness in removing agrochemicals and sediments from field runoff (Zhang and Zhang, 2011). Strip cropping increases surface roughness by applying bands of other crops within an agricultural area to retain pesticide transported by stream flow and sediment while VFS applies a dense vegetation strip such as bush between crop fields and streams to retain sediment and remove sediment attached pesticides (Wang et al., 2019). In terms of the grassed waterway, it is a shallow vegetated channel between fields, prolonging flow retention time and sediment-attached pesticides trapping efficiency. With regard to the sediment ponds or constructed wetlands (CWs), these are impoundments receiving pesticide runoffs, which assist in removing suspended solids and associated pesticides from water phase. Pesticides in dissolved phase would also experience extended retention time for dissipation and degradation processes. Liu et al. (2019) reported that CWs were a cost-effective approach for non-point-source pesticide pollution, and they found organophosphorus pesticides were efficiently removed by up to $87.22 \% \pm 16.61 \%$. Vymazal and Březinová (2015) revealed that removal of pesticides was highly variable, with the highest pesticide removal for organochlorine, strobilurin/strobin, organosphosphate and pyrethroid groups and the lowest removals for the triazinone, aryloxyalkanoic acid and urea groups. Pesticide use reduction refers to the integrated pest management practices including pest pressure monitoring to avoid dormant-season application, biological control, the use of reduced risk pesticides and innovative sprayer technologies to increase spray precision and reduce total pesticide use (Zhang et al., 2008; Zhang and Zhang 2011). It was reported that single BMP practice such as sediment ponds could only trap less than $10 \%$ of dissolved diazinon and chlorpyrifos while coupling individual BMPs (i.e. vegetated ditches, buffer strips and use reduction) could provide enhanced mitigation effects, reducing diazinon and chlorpyrifos load by over 94\% (Zhang and Zhang 2011). Non-structural BMPs refer to any management approaches which are not via establishing on-site physical structures, allowing the reduction of pesticide loadings. Holvoet et al. (2007) employed the cover crops or residue management to cover bare soils and prevent erosion and pesticide loss while Farrand and Heidenreich (2000) proposed alternating pesticide application dates to avoid major precipitation events.

BMP is mostly related to individual engineering practices, whereas LID and GI more often indicate macroscopic planning and development for an entire urban area (Zhang and Chui, 2018). LID represents practices implemented on-site to preserve the pre-development hydrology of a given site using decentralized, micro-scale control measures including bioretention, grass swales and channels, green rooftops, and rain barrels to control the quality and quantity of pesticides-polluted stormwater runoff (US EPA, 2000; Baek et al., 2015). GI is similar to LID, but also represents a network of green spaces and corridors with objectives beyond stormwater management, such as maximizing ecosystem services, watershed restoration, and biodiversity conservation (CNT, 2010; Fletcher et al., 2015). More than 30 cities in China have put forward an innovative urban stormwater management concept based on LID, known as "sponge city", which has brought about the implementation of more than US $\$ 10$ billion worth of BMP-LID-GI practices within the last three years (Ji and Li, 2016; Li et al., 2016; 2018). However, studies on evaluating the performance of those practices on removing specific pesticides from stormwater runoffs are rather limited and require urgent attention.

\section{Future perspectives}

A detailed review of previous studies has revealed that the pesticides in stormwater runoff originated from various sources. Moreover, it is not easy to establish criteria to compare the occurrence of pesticides in stormwater runoff because each study focused on an individual pesticide using its distinct pesticide use pattern in its own local weather conditions. Pesticide emerged as a highly variable constituent in the stormwater runoff in terms of concentration and spatial distribution. However, the reasons behind this variability are still not clearly understood, since studies that focus on the key drivers behind pesticide contamination in stormwater runoff are rare (Zhang et al., 2015). This could be a key knowledge gap hindering the development of control measures for pesticides in stormwater runoff, which is vital both for the protection of ecosystems and the future use of stormwater as a potable water resource. There is still a lack of research and data to promote reliable prediction of pesticide concentrations in stormwater runoff and the impact on downstream water qualities. Research on broadening the knowledge of the various physicochemical, biological and hydrological processes involved (and their interactions) in pesticides' pathway and occurrence in stormwater runoff is therefore urgently needed. Particularly, research investments are needed for a better understanding of the environmental fate and 
behavior of pesticides in order to lower the probability of pesticide pollution from agricultural and urban lands. Furthermore, research that produces reliable predictive models that can estimate pesticide losses and regulate pesticide behavior is required, not only in agricultural and urban stormwater runoff contexts but also during the transit between the two (Willis and McDowell, 1982). It is vital to achieve these research goals and what is demanded, is long-term commitments of resources, and all the key stakeholders in this area helping to generate an objective assessment for both agricultural and urban sectors.

\section{Conclusions}

In recent years, stormwater has been viewed as an effective alternative for potable drinking water supplies, but pesticides have been identified as a possible barrier to make this possible. This paper reviewed the sources and occurrences of pesticides in stormwater runoff in rural and urban areas. Results indicated many possible pathways of pesticides into stormwater runoff. In most cases, the occurrences and concentrations of pesticides varied significantly, and these were closely related to factors such as characteristics of precipitation, pesticide fate properties, pesticides use pattern, and properties of the application surface. These factors should be carefully monitored for the effective control of pesticides in stormwater runoff and environmental contamination in aquatic environments. A few sustainable stormwater management practices are also discussed in the paper as possible measures for removing pesticides from stormwater runoff.

Acknowledgements This review study was supported by the Centre for Technology in Water and Wastewater (CTWW), University of Technology Sydney (UTS, project FEIT- RIA NGO).

\section{References}

Baek S S, Choi D H, Jung J W, Lee H J, Lee H, Yoon K S, Cho K H (2015). Optimizing low impact development (LID) for stormwater runoff treatment in urban area, Korea: Experimental and modeling approach. Water Research, 86: 122-131

Battaglin W A, Smalling K L, Anderson C, Calhoun D, Chestnut T, Muths E (2016). Potential interactions among disease, pesticides, water quality and adjacent land cover in amphibian habitats in the United States. Science of the Total Environment, 566- 567: 320 332

Bollmann U E, Vollertsen J, Carmeliet J, Bester K (2014). Dynamics of biocide emissions from buildings in a suburban stormwater catchment: Concentrations, mass loads and emission processes. Water Research, 56: 66-76

Bucheli T D, Muller S R, Heberle S, Schwarzenbach R P (1998a). Occurrence and behavior of pesticides in rainwater, roof runoff, and artificial stormwater infiltration. Environmental Science \& Technology, 32(22): 3457-3464

Bucheli T D, Müller S R, Voegelin A, Schwarzenbach R P (1998b). Bituminous roof sealing membranes as major sources of the herbicide $(R, S)$-mecoprop in roof runoff waters: Potential contamination of groundwater and surface waters. Environmental Science \& Technology, 32(22): 3465-3471

Burant A, Selbig W, Furlong E T, Higgins C P (2018). Trace organic contaminants in urban runoff: Associations with urban land-use. Environmental International, 242(Pt B): 2068-2077

Chinen K, Lau S L, Nonezyan M, McElroy E, Wolfe B, Suffet I H, Stenstrom M K (2016). Predicting runoff induced mass loads in urban watersheds: Linking land use and pyrethroid contamination. Water Research, 102: 607-618

CNT (2010). The Value of Green Infrastructure: A Guide to Recognizing Its Economic, Environmental and Social Benefits. Proceedings of the Water Environment Federation. Chicago: Center for Neighborhood Technology

Domagalski J (1996). Pesticides and pesticide degradation products in stormwater runoff: Sacramento River Basin, California. Water Resources Bulletin, 32(5): 953-964

Farrand D T, Heidenreich, L K (2000). Monroe City Route J Watershed: Environmental Analysis. U S. Monroe: Food \& Agricultural Policy Research Institute (FAPRI), University of Missouri

Fletcher T D, Shuster W, Hunt W F, Ashley R, Butler D, Arthur S, Trowsdale S, Barraud S, Semadeni-Davies A, Bertrand-Krajewski J L, Mikkelsen P S, Rivard G, Uhl M, Dagenais D, Viklander M (2015). SUDS, LID, BMPs, WSUD and more- the evolution and application of terminology surrounding urban drainage. Urban Water Journal, 12(7): 525-542

Gasperi J, Sebastian C, Ruban V, Delamain M, Percot S, Wiest L, Mirande C, Caupos E, Demare D, Kessoo M D, Saad M, Schwartz J J, Dubois P, Fratta C, Wolff H, Moilleron R, Chebbo G, Cren C, Millet M, Barraud S, Gromaire M C (2014). Micropollutants in urban stormwater: Occurrence, concentrations, and atmospheric contributions for a wide range of contaminants in three French catchments. Environmental Science and Pollution Research, 21(8): 5267-5281

Glinski D A, Purucker S T, Van Meter R J, Black M C, Henderson W M (2018). Analysis of pesticides in surface water, stemflow, and throughfall in an agricultural area in South Georgia, USA. Chemosphere, 209: 496-507

Holvoet K, Gevaert V, van Griensven A, Seuntjens P, Vanrolleghem P A (2007). Modelling the effectiveness of agricultural measures to reduce the amount of pesticides entering surface waters. Water Resources Management, 21(12): 2027-2035

Huang X, Pedersen T, Fischer M, White R, Young T M (2004a). Herbicide runoff along highways. 2. Sorption control. Environmental Science \& Technology, 38(12): 3272-3278

Huang X, Pedersen T, Fischer M, White R, Young T M (2004b). Herbicide runoff along highways. 1. Field observations. Environmental Science \& Technology, 38(12): 3263-3271

Hudak P F, Banks K E (2006). Compositions of first flush and composite storm water runoff in small urban and rural watersheds, north-central Texas. Urban Water Journal, 3(1): 43-49

Ji C, Li L (2016). Research on sponge city construction in Lin Yi city. In: Proceedings of the 2016 International Conference on Education, 
Management, Computer and Society, Shenyang, China, 1-3 January 2016. Paris: Atlantis Press, 1818-1821

Jiang W, Haver D, Rust M, Gan J (2012). Runoff of pyrethroid insecticides from concrete surfaces following simulated and natural rainfalls. Water Research, 46(3): 645-652

Johnson A C (1995). The use of mini-lysimeters to study the influence of rainfall intensity on pesticide transport and water pathways. In: Walker A, ed. Pesticide Movement to Water. Bracknell: British Crop Protection Council, BCPC Monograph No. 62, 33-38

Jorgenson B C, Young T M (2010). Formulation effects and the offtarget transport of pyrethroid insecticides from urban hard surfaces. Environmental Science \& Technology, 44(13): 4951-4957

Jurado A, Vàzquez-Suñé E, Carrera J, López de Alda M, Pujades E, Barceló D (2012). Emerging organic contaminants in groundwater in Spain: A review of sources, recent occurrence and fate in a European context. Science of the Total Environment, 440: 82-94

Konstantinou I K, Hela D G, Albanis T A (2006). The status of pesticide pollution in surface waters (rivers and lakes) of Greece. Part I. Review on occurrence and levels. Environmental Pollution, 141(3): $555-570$

Kratzer C R (1988). Pesticides in Storm Runoff from Agricultural and Urban Areas in the Tuolumne River Basin in the Vicinity of Modesto, California, Water-Resources Investigations Report 98-4017. Menlo Park: US Geological Survey, Branch of Information Services

Li C, Liu M, Hu Y, Han R, Shi T, Qu X, Wu Y (2018). Evaluating the hydrologic performance of low impact development scenarios in a micro urban catchment. International Journal of Environmental Research and Public Health, 15(2): 273-287

Li X, Li J, Fang X, Gong Y, Wang W (2016). Case studies of the sponge city program in China. In: World Environmental and Water Resources Congress 2016. West Palm Beach: ASCE

Liu T, Xu S, Lu S, Qin P, Bi B, Ding H, Liu Y, Guo X, Liu X (2019). A review on removal of organophosphorus pesticides in constructed wetland: Performance, mechanism and influencing factors. Science of the Total Environment, 651(Pt 2): 2247-2268

Luo Y, Guo W, Ngo H H, Nghiem L D, Hai F I, Zhang J, Liang S, Wang X C (2014). A review on the occurrence of micropollutants in the aquatic environment and their fate and removal during wastewater treatment. Science of the Total Environment, 473-474: 619-641

Mangiafico S S, Newman J, Merhaut D J, Gan J, Faber B, Wu L S (2005). Nutrients and pesticides in stormwater runoff and soil water in production nurseries and citrus and avocado groves in California. HortTechnology, 19(2): 360-367 https://doi.org/10.21273/ HORTSCI.19.2.360

Müller KTrolove M, James T K, Rahman A, (2004). Herbicide loss in runoff: Effects of herbicide properties, slope, and rainfall intensity. Australian Journal of Soil Research, 42(1): 17-27

Nakano Y, Miyazaki A, Yoshida T, Ono K, Inoue T (2004). A study on pesticide runoff from paddy fields to a river in rural region-1: field survey of pesticide runoff in the Kozakura River, Japan. Water Research, 38(13): 3017-3022

Oltmann R N, Shulters M V (1989). Rainfall and Runoff Quantity and Quality Characteristics of Four Urban Land-use Catchments in Fresno, California. October 1981 to April 1983. US Geological Survey Water-Supply Paper 2335. Menlo Park: United States Geological Survey
Parker J K, McIntyre D, Noble R T (2010). Characterizing fecal contamination in stormwater runoff in coastal North Carolina, USA. Water Research, 44(14): 4186-4194

Polkowska Ż, Grynkiewicz M, Zabiegala B, Namieśnik J (2001). Levels of pollutants in runoff water from roads with high traffic intensity in the city of Gdansk, Poland. Polish Journal of Environmental Studies, 10(5): 351-363

Polkowska Ż, Tobiszewski M, Górecki T, Namieśnik J (2009). Pesticides in rain and roof runoff waters from an urban region. Urban Water Journal, 6(6): 441-448

Reichenberger S, Bach M, Skitschak A, Frede H G (2007). Mitigation strategies to reduce pesticide inputs into ground- and surface water and their effectiveness: A review. Science of the Total Environment, 384(1-3): 1-35

Revitt D M, Ellis J B, Llewellyn N R (2002). Seasonal removal of herbicides in urban runoff. Urban Water, 4(1): 13-19

Rippy M A, Deletic A, Black J, Aryal R, Lampard J L, Tang J Y M, McCarthy D, Kolotelo P, Sidhu J, Gernjak W (2017). Pesticide occurrence and spatio-temporal variability in urban run-off across Australia. Water Research, 115: 245-255

Sandin M, Piikki K, Jarvis N, Larsbo M, Bishop K, Kreuger J (2018). Spatial and temporal patterns of pesticide concentrations in streamflow, drainage and runoff in a small Swedish agricultural catchment. Science of the Total Environment, 610- 611: 623-634

Stachel B, Holthuis J U, Schulz W, Seitz W, Weber W H, Tegge K T, Dobner I (2010). Treatment techniques and analysis of stormwater run-off from roads in Hamburg, Germany. In: Fatta-Kassinos D, Bester K, Kummerer K, eds. Xenobiotics in the Urban Water Cycle: Mass Flows, Environmental Processes, Mitigation and Treatment Strategies, Environmental Pollution. Dordrecht: Springer Science + Business Media B.V., 16: 455-461

Stephenson G R, Ferris I G, Holland P T, Nordberg M (2006). Glossary of terms relating to pesticides (IUPAC recommendations 2006). Pure and Applied Chemistry, 78(11): 2075-2154

Topaz T, Egozi R, Eshel G, Chefetz B (2018). Pesticide load dynamics during stormwater flow events in Mediterranean coastal streams: Alexander stream case study. Science of the Total Environment, 625: 168-177

US EPA (2000). Low Impact Development (LID): A Literature Review. 20460 (EPA-841-B-00-005). Washington, DC: United States Environmental Protection Agency

US EPA (2011). Pesticide Industry Sales and Usage 2006 and 2007 Market Estimates. Washington DC: Biological and Economic Analysis Division, Office of Pesticide Programs, Office of Chemical Safety and Pollution Prevention, US Environmental Protection Agency

Vialle C, Sablayrolles C, Silvestre J, Monier L, Jacob S, Huau M C, Montrejaud-Vignoles M (2013). Pesticides in roof runoff: Study of a rural site and a suburban site. Journal of Environmental Management, 120: 48-54

Vymazal J, B Třezinová (2015). The use of constructed wetlands for removal of pesticides from agricultural runoff and drainage: A review. Environment International, 75: 11-20

Wang R, Yuan Y, Yen H, Grieneisen M, Arnold J, Wang D, Wang C, Zhang M (2019). A review of pesticide fate and transport simulation at watershed level using SWAT: Current status and research concerns. 
Science of the Total Environment, 669: 512-526

Weston D P, Holmes R W, Lydy M J (2009). Residential runoff as a source of pyrethroid pesticides to urban creeks. Environmental Pollution, 157(1): 287-294

Willis G H, McDowell L L (1982). Pesticides in agricultural runoff and their effects on downstream water quality. Environmental Toxicology and Chemistry, 1(4): 267-279

Wittmer I K, Bader H P, Scheidegger R, Singer H, Lück A, Hanke I, Carlsson C, Stamm C (2010). Significance of urban and agricultural land use for biocide and pesticide dynamics in surface waters. Water Research, 44(9): 2850-2862

Zabik J M, Seiber J N (1993). Atmospheric transport of organophosphate pesticides from California's Central Valley to the Sierra Nevada Mountains. Journal of Environmental Quality, 22(1): 80-90

Zhang K, Chui T F M (2018). A comprehensive review of spatial allocation of LID-BMP-GI practices: Strategies and optimization tools. Science of the Total Environment, 621: 915-929
Zhang K, Randelovic A, Aguiar L M, Page D, McCarthy D T, Deletic A (2015). Methodologies for pre-validation of biofilters and wetlands for stormwater treatment. PLoS One, 10(5): e0125979

Zhang W, Ye Y, Hu D, Ou L, Wang X (2010). Characteristics and transport of organochlorine pesticides in urban environment: air, dust, rain, canopy throughfall, and runoff. Journal of Environmental Monitoring, 12(11): 2153-2160

Zhang W, Ye Y, Tong Y, Ou L, Hu D, Wang X (2011). Contribution and loading estimation of organochlorine pesticides from rain and canopy throughfall to runoff in an urban environment. Journal of Hazardous Materials, 185(2-3): 801-806

Zhang X, Liu X, Luo Y, Zhang M (2008). Evaluation of water quality in an agricultural watershed as affected by almond pest management practices. Water Research, 42(14): 3685-3696

Zhang X, Zhang M (2011). Modeling effectiveness of agricultural BMPs to reduce sediment load and organophosphate pesticides in surface runoff. Science of the Total Environment, 409(10): 1949-1958 